\title{
Forward Modeling Time-Lapse Seismic based on Reservoir Simulation Result on The CCS Project at Gundih Field, Indonesia
}

\author{
Ariesty R. K. Asikin ${ }^{1}$, Awali Priyono ${ }^{1}$, Tutuka Ariadji ${ }^{1}$, Benyamin Sapiie ${ }^{1}$, Mohammad R. Sule ${ }^{1}$, Takeshi Tsuji ${ }^{2}$, \\ Wawan Gunawan A. Kadir ${ }^{1}$, Toshifumi Matsuoka ${ }^{2,4} \&$ Sigit Rahardjo $^{3}$ \\ ${ }^{1}$ Institut Teknologi Bandung, Indonesia \\ ${ }^{2}$ Department of Earth Resources Engineering, Kyushu University, Japan \\ ${ }^{3}$ Upstream Research Technology Center, PT Pertamina, Indonesia \\ ${ }^{4}$ Fukada Geological Institute, Japan \\ Correspondence: Ariesty R. K. Asikin, Jl. Ganesha no. 10, BSCB Building $2^{\text {nd }}$ floor, Bandung, 40132, Indonesia. \\ Tel: 62-8157-351-5558. E-mail: ariestyasikin@gmail.com
}

Received: November 20, 2017

Accepted: November 30, 2017

Online Published: December 25, 2017

doi:10.5539/mas.v12n1p75

URL: https://doi.org/10.5539/mas.v12n1p75

\begin{abstract}
This paper contains reservoir simulation study of carbon storage at Gundih field in Central Java Island, Indonesia. Two different cases of injection simulation were performed and analyzed in this paper. The cases represent the conditions when the smallest and largest volumes of $\mathrm{CO}_{2}$ are injected into the subsurface to see the changes of reservoir that happen after the injection processes. The simulation result shows that when a larger amount of $\mathrm{CO}_{2}$ is injected into the targeted reservoir, it will migrate to the peak of anticline structure located in the southeast of $\mathrm{CO}_{2}$ injection well. The displacement of $\mathrm{CO}_{2}$ in the simulation progress shows that it will not reach the fault location. The geological model for synthetic seismogram calculation is then built based on the simulation reservoir result. The furthest displacement of $\mathrm{CO}_{2}$ is calculated on each case and described as the saturated $\mathrm{CO}_{2}$ layers. Forward modeling is performed to create synthetic seismic gather which will be processed to construct seismic section. The difference between the initial seismic section before the injection process and seismic section including saturated $\mathrm{CO}_{2}$ layer after the injection process will be evaluated by the potential of injected $\mathrm{CO}_{2}$ monitoring using time-lapse seismic survey in the Gundih field.
\end{abstract}

Keywords: CCS, Gundih, reservoir simulation, time-lapse seismic

\section{Introduction}

Gundih field is a gas-producing field located in Central Java. It is assigned to be the first pilot project for Carbon Storage in Indonesia. In every CCS (Carbon Capture Storage) project, $\mathrm{CO}_{2}$ leakage through available fault needs to be avoided; therefore, the migration of injected $\mathrm{CO}_{2}$ should be observed. After the reservoir characterization phase has been completed in the Gundih project (Asikin, et al., 2017), the next step to be done is the reservoir simulation phase. The reservoir simulation is very important to the procedures of $\mathrm{CO}_{2}$ geological storage project, because we can evaluate the movement of the injected $\mathrm{CO}_{2}$ within the reservoir. If this study is scaled up from a pilot project into a demonstration or even a commercial project, the maximum amount of $\mathrm{CO}_{2}$ that can be injected will also increase with longer injection time. Therefore, several scenarios have been created which have different rates and length of injection to represent different stages of the Carbon Storage project in Gundih area. This study will focus on the area around Jepon-1 well, covered by $2 \times 1.5 \mathrm{~km}^{2}$ pseudo 3D seismic data which is acquired in 2016. The information of $\mathrm{CO}_{2}$ distribution in reservoir is also important to realize the effective (low-cost) $\mathrm{CO}_{2}$ storage, because we can use the information in the design of $\mathrm{CO}_{2}$ injection wells.

Central Processing Plant (CPP) is available on the production field area to separate the produced gas from the unwanted gas, including $\mathrm{CO}_{2}$. The $\mathrm{CO}_{2}$ gas will be transported to the Jepon-1 Well, located about $22 \mathrm{~km}$ on the northern side of Gundih field. The CPP of Gundih field emits about 800 ton/day of $\mathrm{CO}_{2}(15.2 \mathrm{MMSCFD})$ which is flared into the atmosphere. In this pilot project, about 30 ton/day of $\mathrm{CO}_{2}(0.57 \mathrm{MMSCFD})$ will be transported from the CPP (Suprapto, et al. 2015). Production gas in Gundih field comes from Kujung limestone formation, and the purified $\mathrm{CO}_{2}$ will be injected in the Jepon-1 Well into Ngrayong sandstone formation. Based on the study of fault seal analysis, the fault in the studied area is sealing type, but we need to consider the additional pressure 
caused by $\mathrm{CO}_{2}$ injection which can be withheld by the fault (Sapiie et al., 2015).

There are 4 trapping mechanisms in $\mathrm{CO}_{2}$ storage: structural trapping, residual trapping, solubility trapping and mineral trapping (IPCC, 2005).In this study the $\mathrm{CO}_{2}$ trapping only takes the structural trapping into account to see how much $\mathrm{CO}_{2}$ can be stored in a short injection, involving free gas or supercritical fluid (Nghiem et al., 2009).

\section{Methods}

\subsection{Reservoir Simulation for Prediction of $\mathrm{CO}_{2}$ Distribution}

Injection simulation is mainly influenced by the physical properties of the reservoir such as porosity, permeability, Net to Gross, water saturation, as well as pressure and temperature condition of the reservoir. Previous study by Onishi et al. (2015) has already been done to try several physical parameter values, in which single value of each property is applied to every simulation process. Meanwhile, in this study, the input grid data is derived from geological modeling that has been built previously by Asikin, et al. (2017). The simulation is done using commercial software Eclipse E300. The results of the injection simulation are then analyzed to determine the spread of injected $\mathrm{CO}_{2}$ beneath the surface.

Since there is only one well in the vicinity of the studied area, the physical properties are distributed using acoustic impedance inversion data. $\mathrm{CO}_{2}$ injection will be performed on Sand B layer which has the depth of 854 $\mathrm{m}$ and the thickness of $8 \mathrm{~m}$. The average porosity range in this layer is $15-18 \%$ and the permeability value ranges from $500 \mathrm{md}$ to $800 \mathrm{md}$ with the average of $600 \mathrm{md}$ (CCS Gundih Team, 2017). Water saturation is considered 1 for all parts of the aquifer to be injected.

Injection pressure constrain of 200 Bar at the bottom hole is used in this study based on the fractured gradient reservoir as the maximum acceptable pressure increase without re-activating an existing fault (Schembre-McCabe, et al, 2007). Reservoir has an initial pressure of $100 \mathrm{Bar}$ and a temperature of $75^{\circ} \mathrm{C}$ in the initial datum depth of $1,000 \mathrm{~m}$. The injection will be carried out when $\mathrm{CO}_{2}$ is already in supercritical state, which is in the pressure condition of $100 \mathrm{Bar}$ with the temperature of $40^{\circ} \mathrm{C}$ (Supratpto, et al., 2016) to reduce pressure compressor for injection (Leits, 2016). With those conditions, the density of supercritical $\mathrm{CO}_{2}$ is assumed to be $628 \mathrm{~kg} / \mathrm{m}^{3}$ in the surface.

Two different cases, which are made from the combination of rate and length of injection, are performed by using the same physical properties and simulation parameters mentioned above. Those cases represent the smallest and largest amount of $\mathrm{CO}_{2}$ that will be injected into the reservoir which will be analyzed then. The first case will perform 30 ton/day of $\mathrm{CO}_{2}$ injection within 2 years period with the total injection of 21,600 ton. This case represents the planned Pilot Project Carbon Storage in Gundih field.The total volume of the injected $\mathrm{CO}_{2}$ in the second case is maximized following the injection rate used by already known commercial project in the world, to know the maximum capacity of aquifer layer in Gundih area. With the rate of injection increased by $100 \mathrm{x}$ from the pilot project, 3,000 tons per day of $\mathrm{CO}_{2}$, which equals to the total of $10.95 \mathrm{Mton}$ of $\mathrm{CO}_{2}$, will be injected into the targeted layer for 10 years.

\subsection{Time-Lapse Seismic Modeling}

Ngrayong Formation was selected to be the targeted reservoir for $\mathrm{CO}_{2}$ injection because the monitoring techniques and methods would be more applicable in shallow reservoir (Srigutomo et al., 2015). In the case of a large amount of $\mathrm{CO}_{2}$ that has been injected into the reservoir, like in Sleipner Project (Eiken et al., 2000), the effect of the injection usually can be seen. However, with only a small amount of $\mathrm{CO}_{2}$ planned to be injected to the Pilot Project Carbon Storage in Gundih area, this forward seismic modeling study needs to ensure whether the seismic signal can capture the injection effect while the targeted layer is located in shallow reservoir.

Pseudo 3D seismic data is obtained using 8 tons of vibroseis due to our circumstances in the field, such as permissions, easy repeatability, and lower cost compared to using dynamite as a source (Bahar et al., 2017). Forward seismic modeling is performed in this study based on the interpretation of the Pseudo 3D seismic model. Physical properties used in this model are obtained from average velocity and density throughout each formation, shown in Table 1. The saturated velocity and density from the injected layer are calculated using Biot Gasmman equations (Mavko, 1998), derived from the known value of properties in the targeted layer filled with different fluids; that is $\mathrm{CO}_{2}$. The saturation value of $\mathrm{CO}_{2}$ follows the simulation result of each case which is 0.08 for the first case and 0.38 for the second case. 
Table 1. Physical properties from each formation (modified from Asikin, 2015)

\begin{tabular}{llll}
\hline Formation & $\begin{array}{l}\text { Velocity }(\mathbf{~} \mathbf{p}) \\
\mathbf{m} / \mathbf{s}\end{array}$ & $\begin{array}{l}\text { Velocity }(\mathbf{V s}) \\
\mathbf{m} / \mathbf{s}\end{array}$ & $\begin{array}{l}\text { Density } \\
\mathbf{K g} / \mathbf{m} \mathbf{3}\end{array}$ \\
\hline Ledok & 2147.76 & 1240.01 & 2.009 \\
Wonocolo & 2742.52 & 1583.394 & 2.2739 \\
Ngrayong & 3008.65 & 1737.048 & 2.4174 \\
$\begin{array}{l}\text { Ngrayong } \\
\left.\text { (Saturated by } 0.08 \mathrm{CO}_{2}\right)\end{array}$ & 2292.91 & 1738.55 & 2,413 \\
$\begin{array}{l}\text { Ngrayong } \\
\left.\text { (Saturated by } 0.38 \mathrm{CO}_{2}\right)\end{array}$ & 2194.32 & 1744.25 & 2.397 \\
Tuban & 3295.075 & 1902.412 & 2.4954 \\
\hline
\end{tabular}

\section{Results}

The simulation is done without adding water injection after $\mathrm{CO}_{2}$ injection although adding water can lower the depth of $\mathrm{CO}_{2}$ plume to prevent a leaking event on the top of the seal, as it is recommended by Putra (2014). The reason is when the fault is located quite close to the injection wells, the water injection can create more $\mathrm{CO}_{2}$ leaking at the fault due to the pressure caused by water injection (Leits, 2016). In the targeted formation, the distance between the targeted anticline structure and the fault is quite near, which is around $400 \mathrm{~m}$ (Tsuji et al., 2014).

The simulation result of the first case is shown in Figure 1. The distribution of gas saturation is analyzed before the injection begins on the first year of injection and on the second year of injection which is the end of injection. The $\mathrm{CO}_{2}$ distribution is also analyzed after the injection is finished to see the movement of the $\mathrm{CO}_{2}$ on the following years. On the second case, the gas distribution on the fifth year of injection and tenth year of injection are analyzed, as shown in Figure 2. Similar to the first case, the distribution of $\mathrm{CO}_{2}$ is also analyzed after the injection ends in one year, ten years and a hundred years.

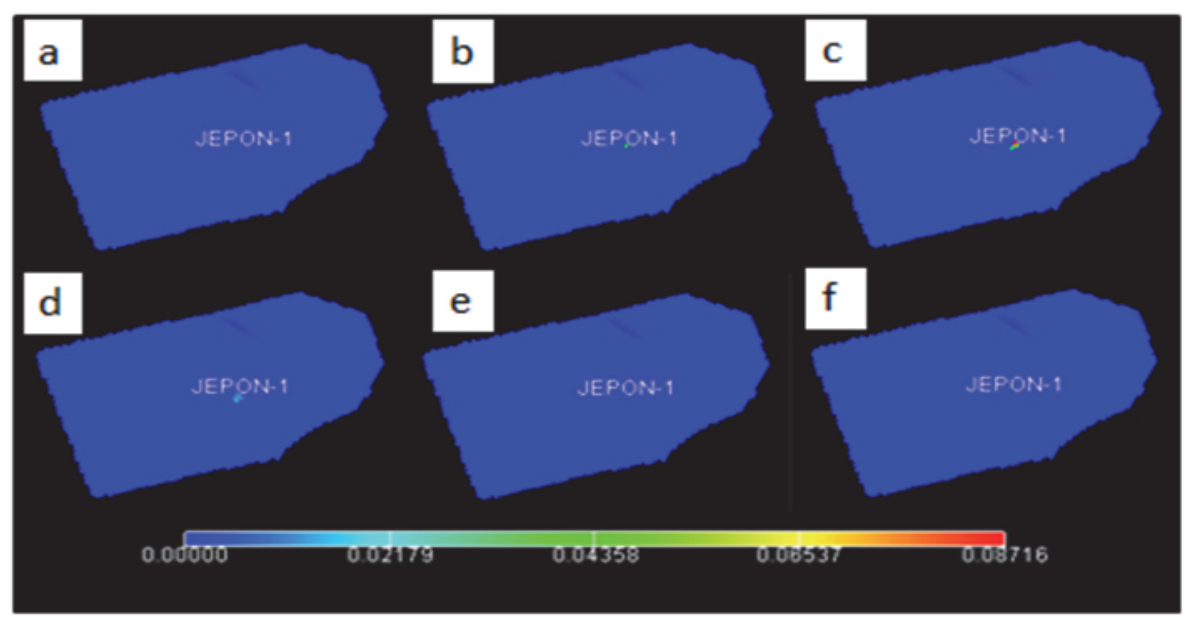

Figure 1. The distribution of gas saturation from simulation result of the first case; (a) condition before the injection begins (b) first year of the injection (c) second year of the injection/the end of the injection (d) one year after the end of the injection (e) ten years after the end of the injection (f) a hundred year after the end of the injection 


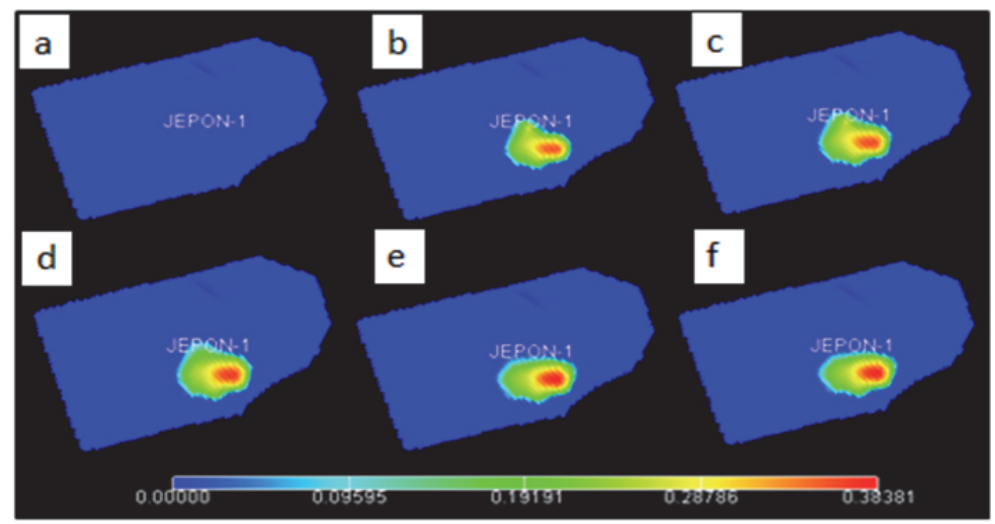

Figure 2. The distribution of gas saturation from simulation result of the second case; (a) condition before the injection begins (b) the fifth year of the injection/the end of the injection (c) the tenth year of the injection/the end of the injection (d) one year after the end of the injection (e) ten years after the end of the injection (f) a hundred years after the end of the injection

Synthetic geological model is built from the interpretation of the inline and crossline data of Pseudo 3D seismic data that past Jepon-1 well, as shown in Figure 3. Four different layers which represent Ledok Formation, Wonocolo Formation, Ngrayong Formation and Tuban Formation are made by using the physical properties described in Table 1. This model represents the condition before the injection begins. Meanwhile, the synthetic geological model in Figure 4 shows the condition of reservoir after ten years of the injection process in the second case.
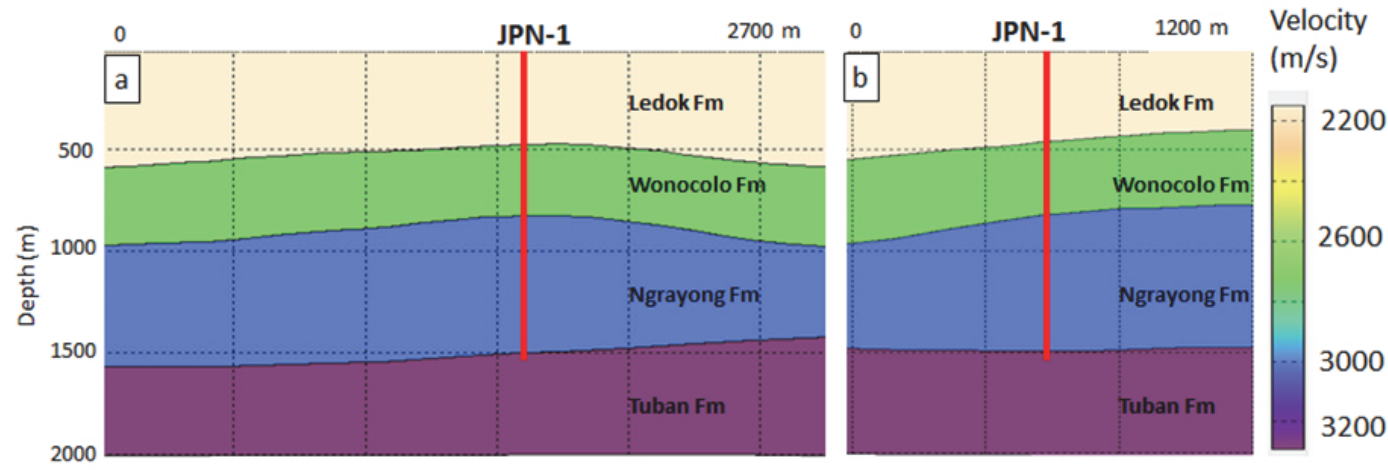

Figure 3. Initial geological model used in forward seismic modeling; (a) the inline section and (b) the crossline section. The first layer (cream color) is the Ledok Formation, the second layer (green) is the Wonocolo Formation, the third layer (blue) is the Ngrayong Formation, and the last layer (purple) is the Tuban Formation. The Jepon-1 well is indicated by a red line

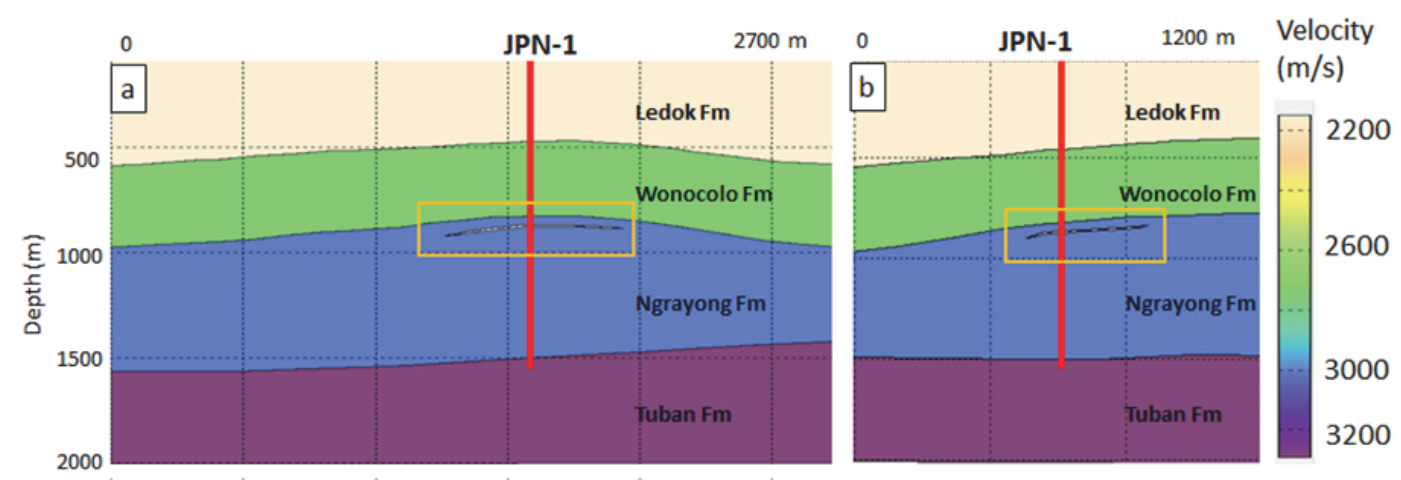

Figure 4. Synthetic geological model similar to Figure 3, with the difference shown in the yellow box representing $\mathrm{CO}_{2}$ saturation from the resevoir simulation result of the second case when the largest amount of $\mathrm{CO}_{2}$ being injected into the reservoir 
The source and receiver intervals are $10 \mathrm{~m}$ of each and the time sample is every $2 \mathrm{~ms}$, following from the previous Pseudo 3D seismic acquisition. This time-lapse seismic modeling is performed by using Tesseral software. Because the dispersion of $\mathrm{CO}_{2}$ on the second case is larger than that on the first case, it is decided to test the seismic responses by using the model in Figure 4 to see the modeling ability in mapping the thin layers. Vertical incidental modeling process is applied in the data to produce the seismic section on the following figure. On the second case where the amount of injected $\mathrm{CO}_{2}$ which is performed is very large, the amplitude change can be detected. It is shown in Figure 6.

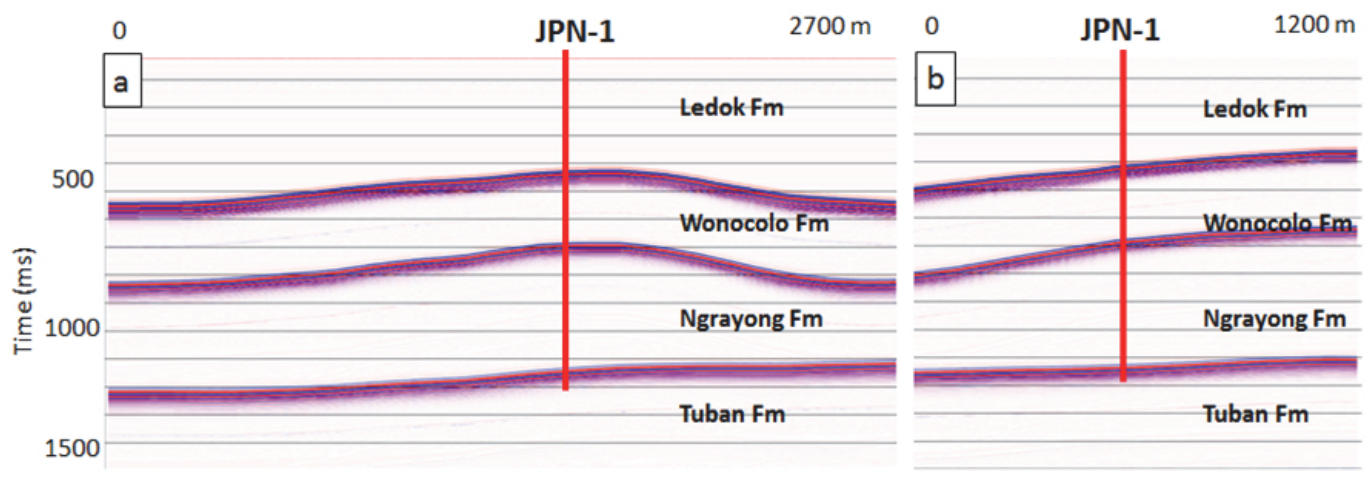

Figure 5. The inline and crossline sections of the initial model in Figure 3

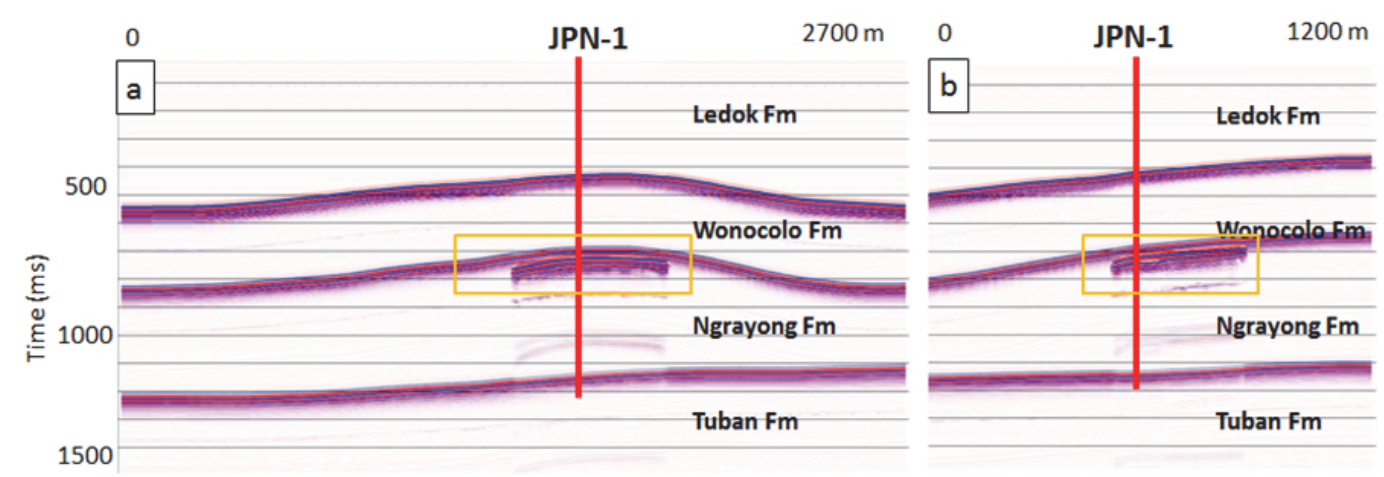

Figure 6. The inline and crossline sections of the synthetic model in Figure 4 that serve as the condition after the injection. The yellow box indicates $\mathrm{CO}_{2}$ effect in the seismic section

One more modeling is performed using the simulation model from the first case where the total injection is only 21,600 tons with a very small $\mathrm{CO}_{2}$ movement. The synthetic geological model that represents the condition of reservoir after two years of injection can be seen in Figure 7. The same acquisition of parameters and processes on the second case are also applied to the synthetic model to generate seismic section in Figure 8.
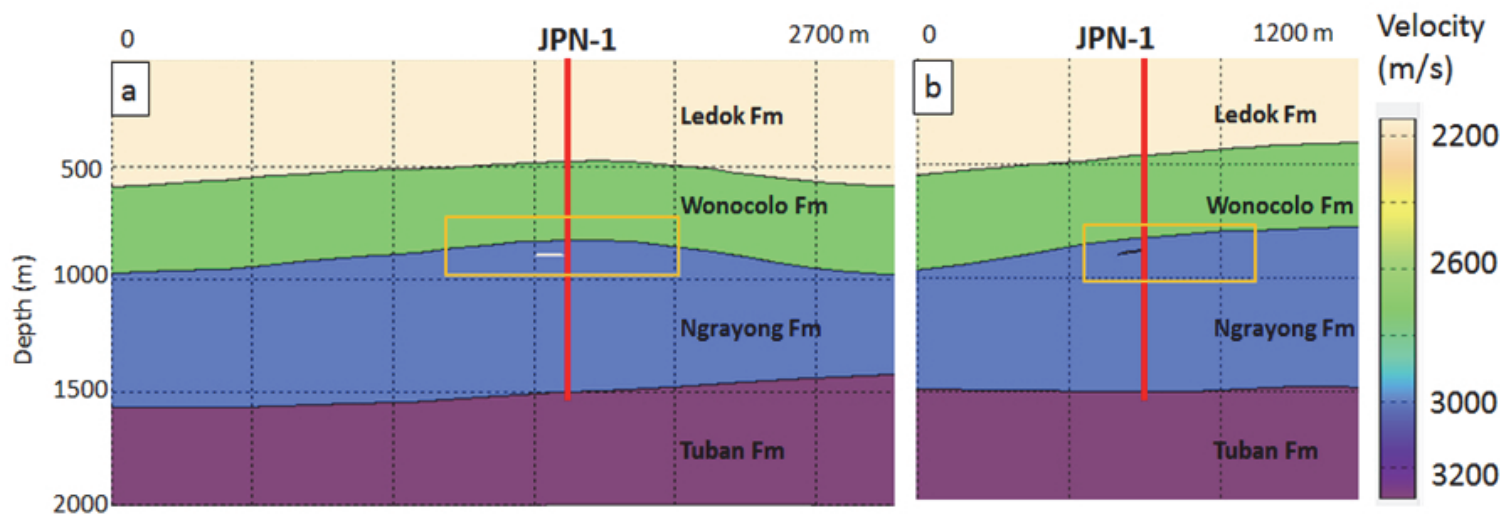

Figure 7. Synthetic geological model of the first case when a smaller amount of $\mathrm{CO}_{2}$ is injected to the reservoir 

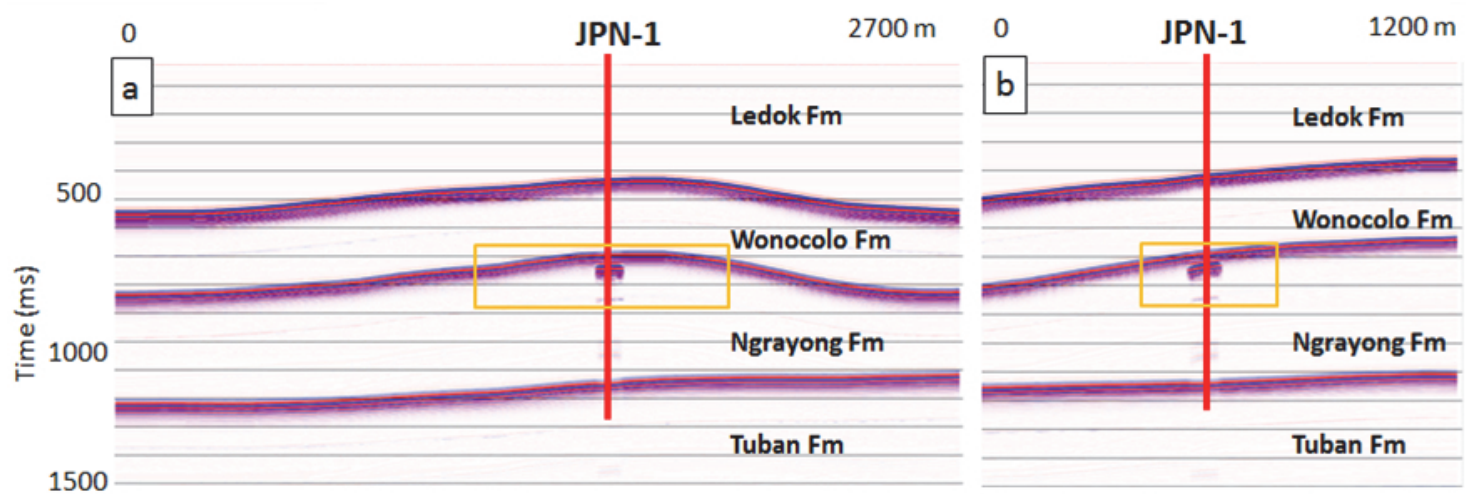

Figure 8. Synthetic seismic section generated from the synthetic model in Figure 7

Ricker wave is used in this study with two different dominant frequencies: $70 \mathrm{~Hz}$ and $30 \mathrm{~Hz}$. The high frequency is used in this modeling to detect Sand B layer as the targeted injected layer which has the thickness of only $8 \mathrm{~m}$. Figure 6 and 8 are modeled using $70 \mathrm{~Hz}$ dominant frequency. However, due to the long required modeling time for high frequency acquisitions, another acquisition is made using $30 \mathrm{~Hz}$ frequency, adjusting the dominant frequency extracted from Pseudo 3D seismic data. The modeling is performed on both cases, as it is shown in Figure 9 and 10. The results of the modeling using the $30 \mathrm{~Hz}$ frequency seem still able to map $\mathrm{CO}_{2}$-saturated layers well. Although it is very small, the amplitude changes can still be detected.
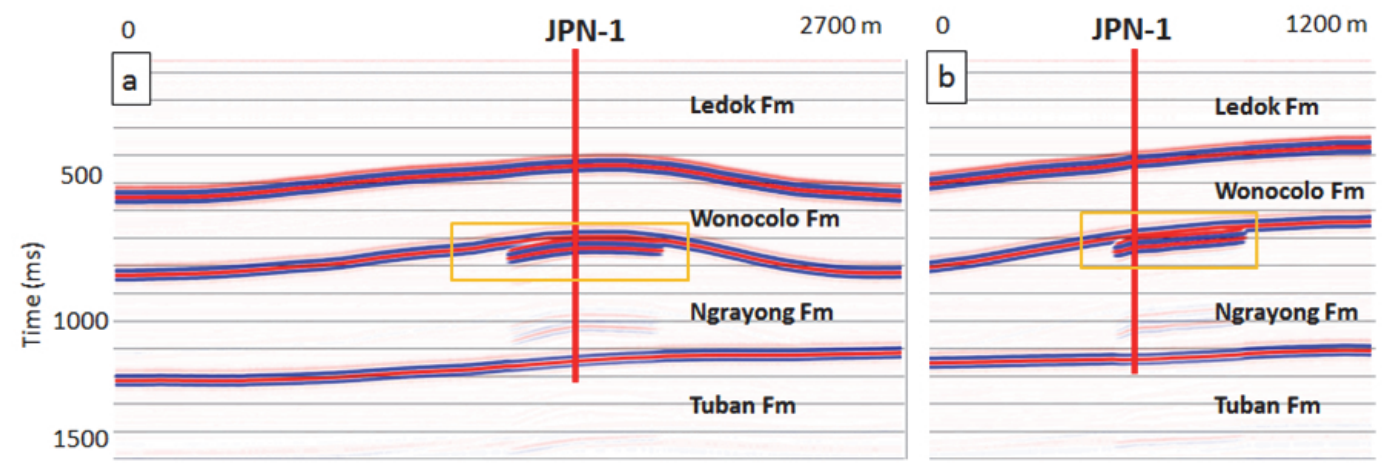

Figure 9. Seismic section from the second case using $30 \mathrm{~Hz}$ of dominant frequency
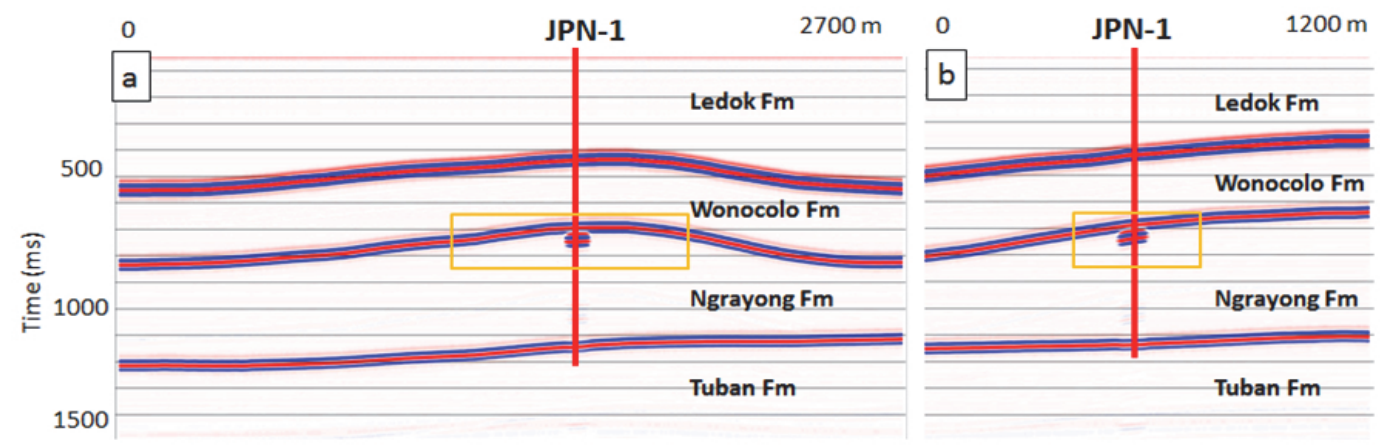

Figure 10. Seismic section from the first case using $30 \mathrm{~Hz}$ of dominant frequency

\section{Discussion}

On the first case where the rate of injection is low (30 ton/day), there is no noticeable change from before, during and after injection. In the properties of gas saturation, the change only occurs around the Jepon- 1 well, as shown in Figure 11. The difference on value indicating the $\mathrm{CO}_{2}$ movement is only $\sim 75 \mathrm{~m}$ from the site of Jepon- 1 well 
at the end of the second year of injection. The $\mathrm{CO}_{2}$ even does not reach the top of the anticline structure, as shown in saturation gas graph in Figure 12(a). Ten years after the injection is done, the gas saturation is not visible or detected. It happens most likely because the $\mathrm{CO}_{2}$ is dissolved with water. The change of value occurred on water saturation is the opposite process of gas saturation. Ten years after the injection, the value of water saturation is back to $100 \%$ as the period of pre-injection. The pressure value is 72.4 Barsa and has increased simply to 72.6 Barsa at the time of the injection (Figure 12(b)). When injection has ended, the pressure is reduced slightly and is in a constant condition of 72.5 Barsa.

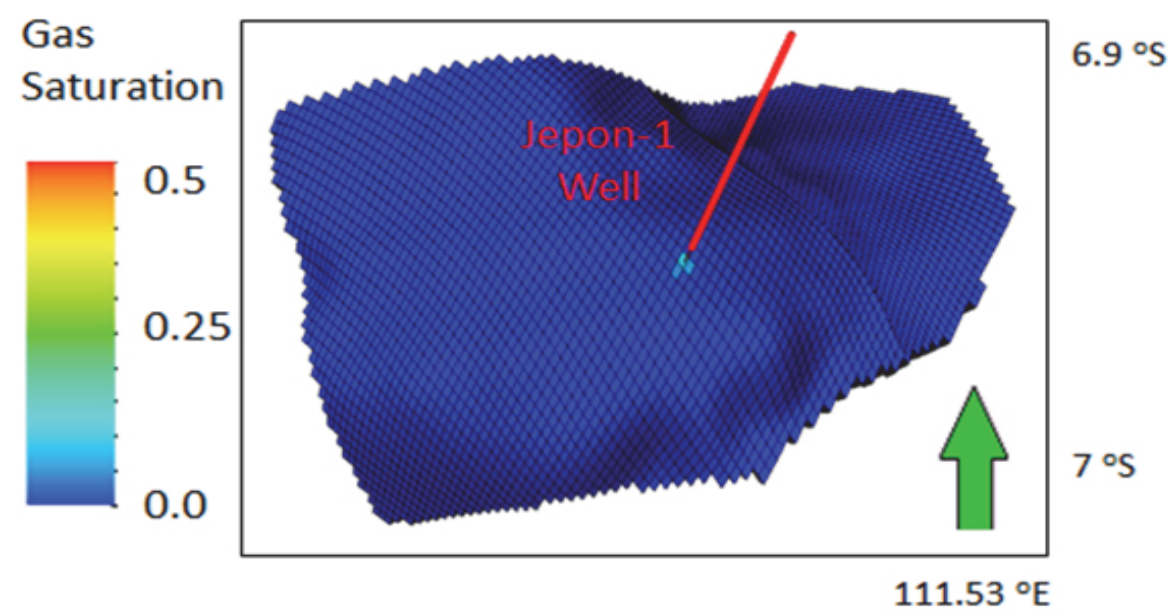

Figure 11. Distribution of $\mathrm{CO}_{2}$ saturation after two years of injection from the first case. The $\mathrm{CO}_{2}$ only spreads in the area around the Jepon- 1 well due to the small total number of injections, within a range of $<100 \mathrm{~m}$ from the injection well
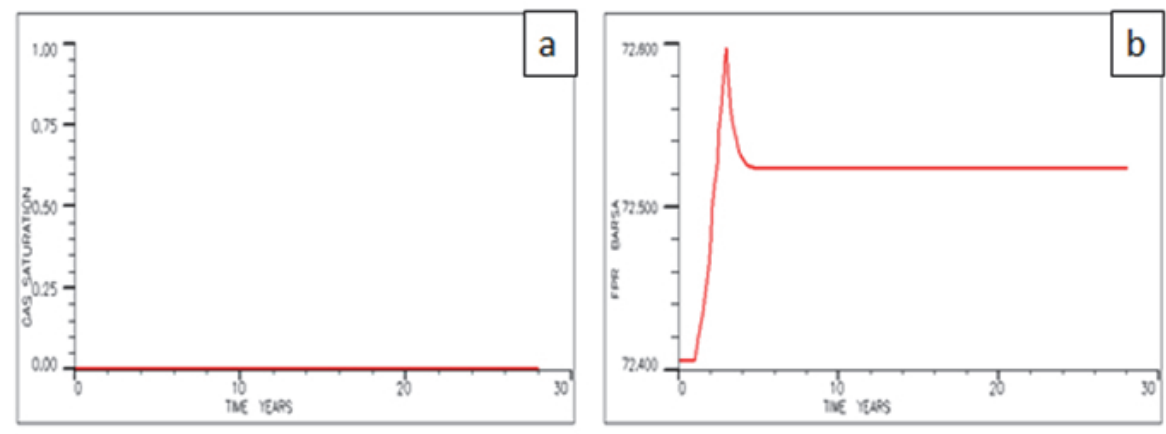

Figure 12. (a) Gas saturation graph that represents $\mathrm{CO}_{2}$ saturation at the peak of the anticline structure; (b) Field pressure distribution graph of the studied area. Both (a) and (b) are produced from the first case simulation

The latter case is completed to know the direction of $\mathrm{CO}_{2}$ movement when the amount of injected $\mathrm{CO}_{2}$ approaches the maximum anticline capacity, ie the injection rate of 3,000 tons per day. In the fifth year of injection, $\mathrm{CO}_{2}$ is detected to move as far as $420 \mathrm{~m}$ on the south west direction from Jepon- 1 Well. When injected, $\mathrm{CO}_{2}$ moves to fill the anticline structure located on the southwest of the injection well. $\mathrm{CO}_{2}$ occupies an area along $520 \mathrm{~m}$ on the direction of east-west and along $430 \mathrm{~m}$ on the direction of north-south. The closest distance from the $\mathrm{CO}_{2}$-filled area to the nearest fault is $\sim 260 \mathrm{~m}$. In the tenth year of the injection, the movement has risen to $627 \mathrm{~m}$ on the east-west direction and $500 \mathrm{~m}$ on the north-south direction, in which the distance to the fault is $\sim 238 \mathrm{~m}$. 


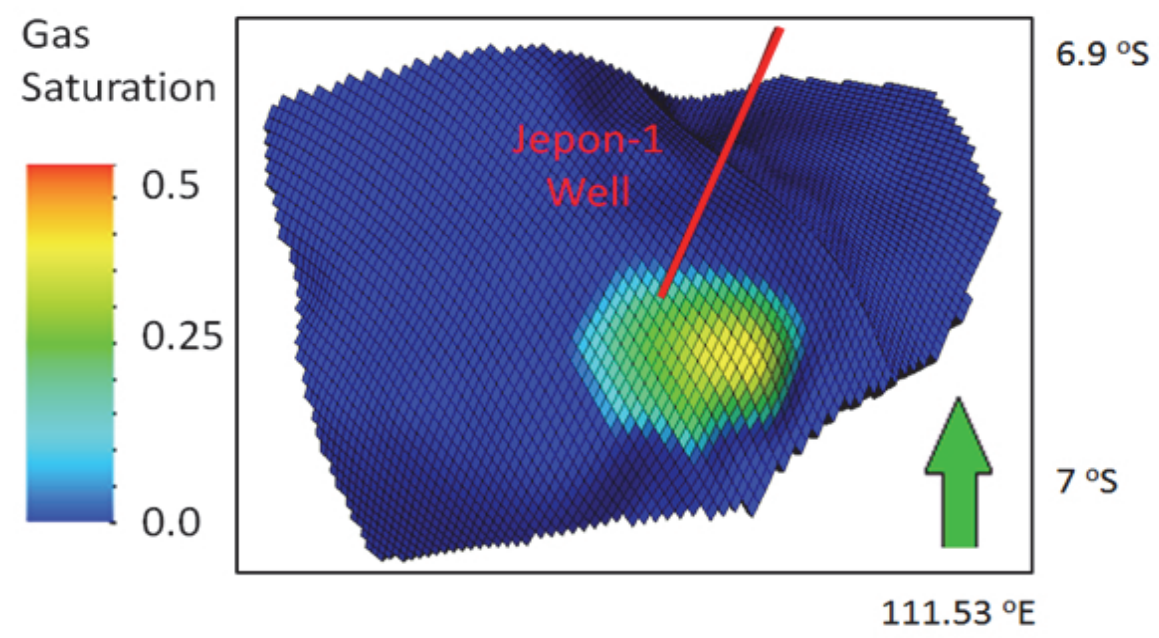

Figure 13. Distribution of $\mathrm{CO}_{2}$ saturation after ten years of injection. The injected $\mathrm{CO}_{2}$ will migrate to the peak of anticline structure even after the injection process ends
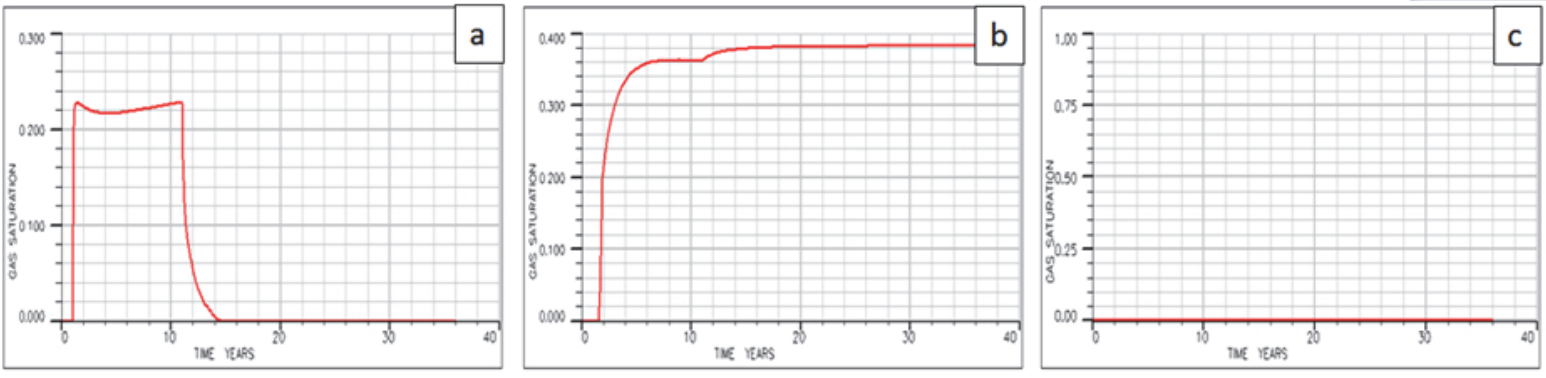

Figure 14. Gas saturation graph from different grid location: (a) at the Jepon-1 well; (b) at the peak of anticline structure; (c) at the nearest fault from the injection well

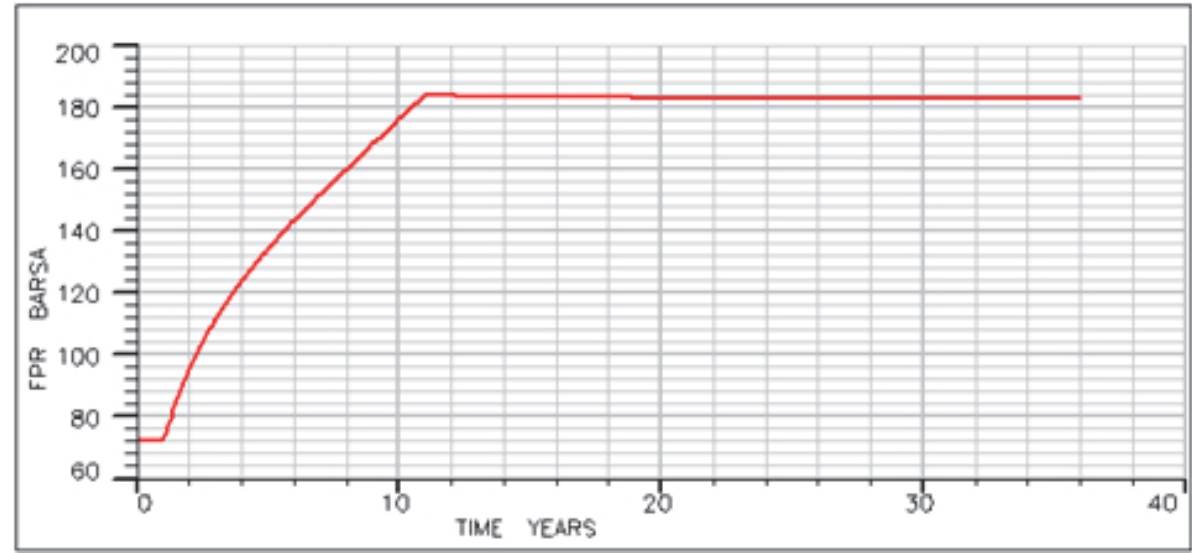

Figure 15. Field pressure distribution graph. The injection process causes an increase in pressure and will remain stable after the injection ends

The maximum gas saturation appears to fill the peak area of the anticline structure as shown in Figure 13. The graph of Figure 14 is made to show the saturation changes occurring on a particular grid. The first graph signifies $\mathrm{CO}_{2}$ saturation at the Jepon-1 Well location and the second graph is the located peak of the anticline. The third graph indicates the changes on the fault area. From the first graph, it can be seen that $\mathrm{CO}_{2}$ in the well increases drastically when the injection begins in the first year, with 0.22 of maximum saturation. The value is relatively constant during the injection that lasts up to 10 years. After the injection stops, the saturation goes back 
to the value before the injection is begun. The second graph shows that in the fifth year of injection, the $\mathrm{CO}_{2}$ saturation at the peak of anticline increases from zero to 0.36 . It also shows that $\mathrm{CO}_{2}$ continues to fill the pore with maximum saturation of 0.38 after tenth year of injection. The saturated area becomes wider in the tenth year of injection, centered at the top of the anticline. After ten years of injection is complete, there is no significant change in the area and in the maximum saturation value as it happens when the injection ends. However, the distribution of pressure at Jepon Area shown in Figure 15 changes significantly from 70 Barsa to 140 Barsa after five years of injection, and later to 180 Barsa after ten years of injection. The pressure distribution remains almost the same after the injection has finished.

Besides of reservoir simulation result, $\mathrm{CO}_{2}$ distribution can also be detected in seismic section. After the reduction on each inline and crossline section between pre and post injection states, amplitude changes to become more apparent. From the higher frequency of $70 \mathrm{~Hz}$ dominant frequency result, the targeted thin layer can be distinguished, as it is shown in Figure 16 and Figure 17. As predicted by the extensive dispersion shown in reservoir simulation result, amplitude changes which are resulted from the second case are well shown on Figure 16. On Figure 17, although the injected amount $\mathrm{CO}_{2}$ is very small, which is 30 ton per day after two years of injection, the changes can be detected around the Jepon-1 well.
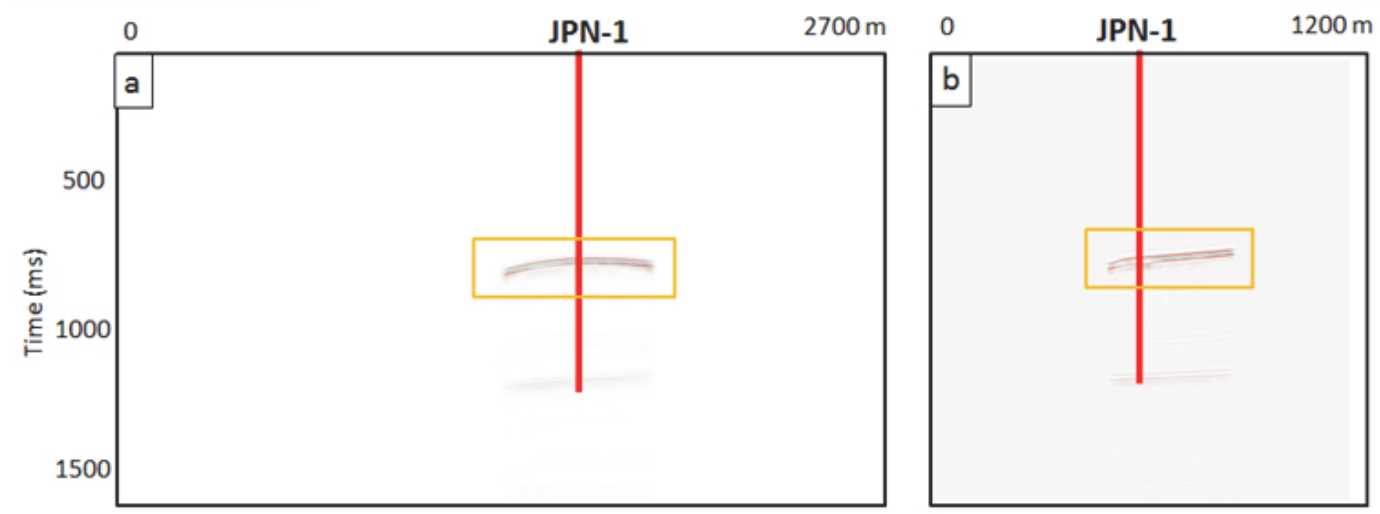

Figure 16. Differences in the inline and crossline sections resultedfrom $\mathrm{CO}_{2}$ injections onthe targeted layer for the second case by using $70 \mathrm{~Hz}$ of dominant frequency
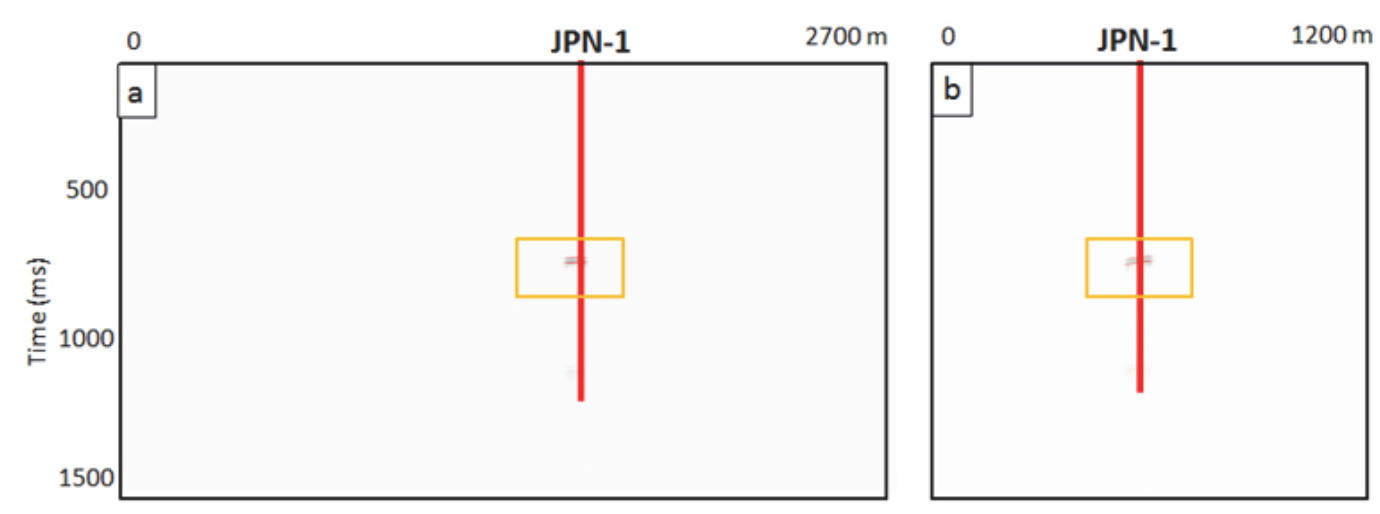

Figure 17. Differences in the inline and crossline sections resulted from $\mathrm{CO}_{2}$ injections on the targeted layer for the first case by using $70 \mathrm{~Hz}$ of dominant frequency

From the result of time-lapse modeling using lower dominant frequency which is $30 \mathrm{~Hz}$, the top of saturated $\mathrm{CO}_{2}$ layer can also be identified as it is shown in Figure 18 and Figure 19. Considering the computation time to create each model and also to synchronize with the actual seismic frequency in real acquisition, the $30 \mathrm{~Hz}$ modeling is good enough to be used to monitor the $\mathrm{CO}_{2}$ distribution. 


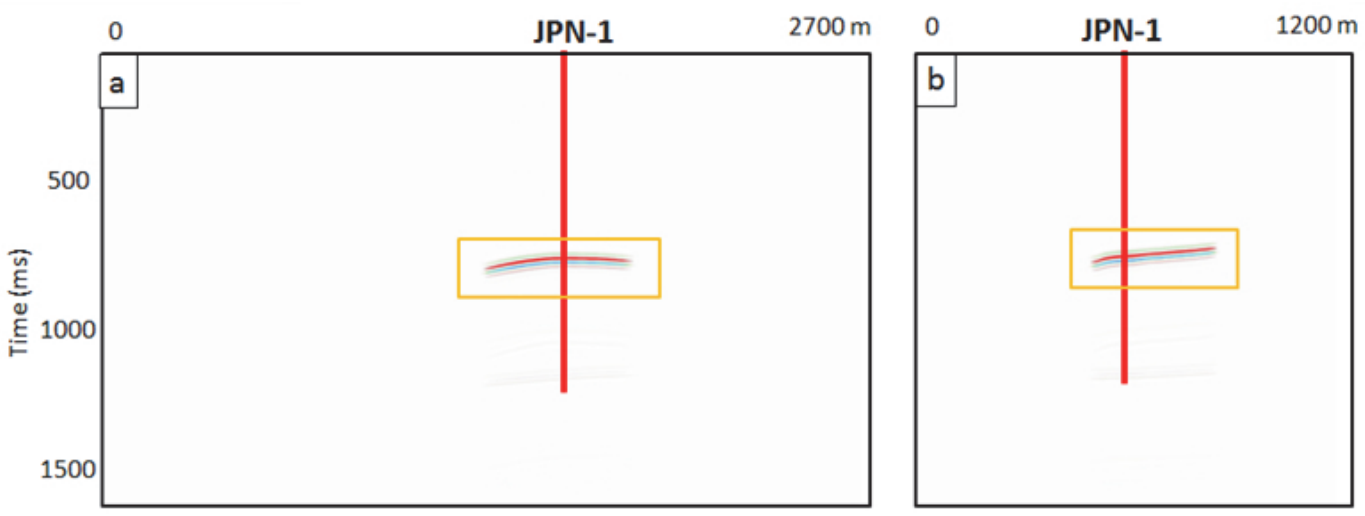

Figure 18. The amplitude change recorded due to $\mathrm{CO}_{2}$ injection on the second case using $30 \mathrm{~Hz}$ of dominant frequency

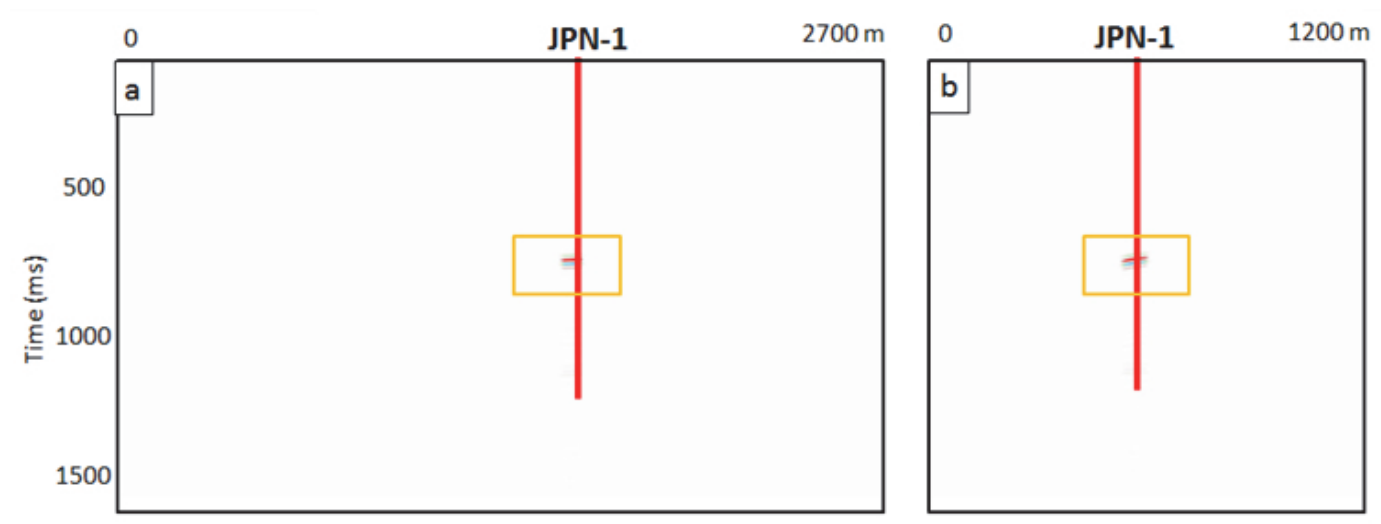

Figure 19. The amplitude change recorded due to $\mathrm{CO}_{2}$ injection on the first case using a frequency of $30 \mathrm{~Hz}$

\section{Conclusion}

The reservoir injection simulation which is performed shows the direction of $\mathrm{CO}_{2}$ migration which tends to flow toward the top of the structure. The direction is to the southeast of the Jepon- 1 well. From different injection scenarios, it can be seen that with a long duration and large injection rate of 100x from the initial target of the study, the anticline structure found in the Jepon- 1 well area can accommodate the $\mathrm{CO}_{2}$ injection. This time-lapse seismic modeling method is able to show the different anomalous response resulted from reservoir injection. Both $30 \mathrm{~Hz}$ and $70 \mathrm{~Hz}$ frequencies can identify the top of saturated $\mathrm{CO}_{2}$ layer. With the initial injection target of CCS Gundih Project, which is 30 ton per day after two years of injection, the amplitude changes can be detected around the Jepon-1 Well.

\section{Acknowledgement}

Authors would like to thank to PT. Pertamina EP for providing data and SATREPS Project for financially supporting this research. Authors also acknowledge the support of all member of Gundih CCS Team.

\section{References}

Andryan, P. (2014). Quantification of influencing parameters of $\mathrm{CO}_{2}$ storage for Gundih area considering residual and solubility trapping using reservoir simulation model and design of experiment (M.Sc. thesis). Institut Teknologi Bandung, Bandung, Indonesia

Arts, R., Eiken, O., Chadwick, A., Zweigel, P., van der Meer, L., \& Zinszner, B. (2004). Monitoring of $\mathrm{CO}_{2}$ Injected at Sleipner Using Time Lapse Seismic Data. $6^{\text {th }}$ International Conference on Greenhouse Gas Control Technologies, 29(9-10),1383-1392. https://doi.org/10.1016/j.energy.2004.03.072

Asikin, A., Priyono, A., Sapiie, B., Ariadji, T., Sule, R., Bahar, A., Tsuji, T., ... Prabowo, H. (2017). Model Derived from Pseudo 3D Seismic Data as a Baseline Model for The Pilot Project of Carbon Capture and Storage in Gundih Gas Field, Central Java, Indonesia. International Journal of Greenhouse and Gas Control. 
(submitted).

Asikin, A., Sule, R., Priyono, A., Tsuji, T., \& Raharjo, S. (2015). Simulation of time lapse seismic for $\mathrm{CO}_{2}$ injection monitoring: preliminary result: Proceedings of 2015 SEGJ International Symposium. Tokyo, Japan. https://doi.org/10.1190/segj122015-028

Bahar, A., Sule, R., Priyono, A., Hato, M., Kozawa, T., Guntara, A. G., ... Matsuoka, T. (2017). Baseline Seismic Survey for Gundih CCS Pilot Project: Proceedings of Joint Convention Malang 2017. Malang, Indonesia.

Eiken, O., Brevik, I., Arts, R. J., Lindeberg, E., \& Fagervik, K. (2000). Seismic monitoring of $\mathrm{CO}_{2}$ injected into a marine aquifer: Proceedings of SEG Calgary 2000 International conference and $70^{\text {th }}$ Annual meeting (paper RC-8.2). Calgary, Canada.

Gundih CCS Team. (2017). Internal report of Gundih CCS Project.

Intergovernmental Panel on Climate Change (IPCC). (2005). Special Report on Carbon Dioxide Capture and Storage, Cambridge University Press.

Leits, A. (2015). AnalisisjebakanstrukturalpadaCO $\mathrm{CO}_{2}$-storage area J (M.Sc. thesis). InstitutTeknologiBandung, Bandung, Indonesia.

Mavko, G., Mukerji, T., \& Dvorkin, J. (1998). The Rock physics handbook. Cambridge University Press.

Nghiem, L., Yang, C., Shrivastava, V., Kohse, B., Hassam, M., \& Card, C. (2009). Risk mitigation through the optimization of residual gas and solubility trapping for $\mathrm{CO}_{2}$ storage in saline aquifer. Energy Procedia, 1, 3015-3022. https://doi.org/10.1016/j.egypro.2009.02.079

Onishi, K., Nguyen, D. T., Fujii, H., Tsuji, T., Hato, M., Takahashi, T., Matsuoka, T., Sule, M. R., Kadir, W. G. A. (2015). Fluid flow simulation for the safety injection of carbon dioxide in Gundih CCS site, Indonesia: Proceedings of 2015 SEGJ International Symposium. Tokyo, Japan. https://doi.org/10.1190/segj122015-026

Sapiie, S., Danio, H., Priyono, A., Asikin, A. R., Widarto, D. S., Widianto, E., \& Tsuji, T. (2015). Geological Characteristic and fault stability of the Gundih CCS pilot project at central Java, Indonesia: Proceedings of 2015 SEGJ International Symposium. Tokyo, Japan. https://doi.org/10.1190/segj122015-029

Schembre-McCabe, J. M., Kamath, J., \& Gurton, R. (2007). Mechanistics Studies of $\mathrm{CO}_{2}$ sequestratio: Proceedings of International Petroleum Technology Conference (Paper IPTC 11391). Dubai, UAE.

Srigutomo, W., Warsa, W., Sule, R., Trimadona, Prasetyo, D., Saito, A., Nakayama K., Hato, M., Prasetyo, A., Widarto, D.S. (2015). Time-domain electromagnetic (TDEM) baseline survey for CCS in Gundih area, Central Java, Indonesia: Proceedings of 2015 SEGJ International Symposium, Tokyo. https://doi.org/10.1190/segj122015-030

Suprapto, H. B. A., Indarto, A., Sule, M. R., Rasrendra, C. B., Dewi, R. G., .. Marbun, B. T. H. (2016). Pilot study carbon capture and storage (CCS) in Indonesia: planning for the CCS pilot facilities at Gundihfield: Proceedings of 2016 Indonesian Petroleum Association, Jakarta.

Suprapto, H. B. A., Sule, M. R., Prabowo, H., Sasongko, D., Dewi, R. G., ... Rasrendra, C. B. (2015). Pilot study carbon capture and storage (CCS) in Indonesia: planning for the CCS pilot facilities at Gundih field: Proceedings of 2015 SEGJ International Symposium, Tokyo. https://doi.org/10.1190/segj122015-027

Tsuji, T., Matsuoka, T., Kadir, W. G. A., Hato, M., Takahashi, T., Sule, M. R., ... Asikin, A.R. (2014). Reservoir Characterization for Site Selection in the Gundih CCS Project, Indonesia.Energy Procedia,63,6335-6343. https://doi.org/10.1016/j.egypro.2014.11.666

\section{Copyrights}

Copyright for this article is retained by the author(s), with first publication rights granted to the journal.

This is an open-access article distributed under the terms and conditions of the Creative Commons Attribution license (http://creativecommons.org/licenses/by/4.0/). 